\title{
Practical aspects of grass forage seed production and quality with particular reference to planting row spacing and nitrogen fertilization in tropical regions: A review
}

\author{
Basile GBENOU ${ }^{1}$, Sébastien ADJOLOHOUN ${ }^{1 *}$, Daniel Bignon Maxime HOUNDJO ${ }^{1}$, \\ Léonard AHOTON ${ }^{2}$, Aliou SAIDOU ${ }^{2}$, Marcel HOUINATO ${ }^{1}$, \\ Soumanou SEIBOU TOLEBA ${ }^{1}$ and Brice Augustin SINSIN $^{3}$ \\ ${ }^{I}$ Département de Production Animale, Faculté des Sciences Agronomiques, \\ Université d'Abomey-Calavi, 03 BP 2819 Jéricho, Cotonou, Benin. \\ ${ }^{2}$ Département de Production Végétale, Faculté des Sciences Agronomiques, \\ Université d'Abomey-Calavi, 03 BP 2819 Jéricho, Cotonou, Benin. \\ ${ }^{3}$ Département de l'Aménagement et Gestion des Ressources Naturelles, Faculté des Sciences \\ Agronomiques, Université d'Abomey-Calavi, 03 BP 2819 Jéricho, Cotonou, Benin. \\ *Corresponding author, E-mail: s.adjolohoun@yahoo.fr, Tél: (+229) 97898851
}

\begin{abstract}
The poor seed yield from some pasture grasses may result from a number of causes, such as the choice of site production, low soil fertility, inappropriate sowing rate, inadequate crop management practices particularly plant density, fertilizer input, poor seed recovery, etc. Compared with sowings of general plant use, seed crops warrant more care and expense during the establishment phase. Seedbeds should be prepared more thoroughly and the seed sown more precisely using adequate seeding rates. The effect of row spacing on the one hand and nitrogen level application on the other hand, have variable effect on grass seed production and there are a conflicting report in some cases depending on species, management practices and environmental conditions, and therefore a case-by-case study for each species and environment is important. In general, seed growers had better to sown seed in row than broadcasting and row spacing of $50-80 \mathrm{~cm}$ can be recommended for seed production depending on grass species or cultivars. The selection of optimal production areas depends on soil fertility, the photoperiod and temperature which can interact with rainfall and humidity of the site. The optimum sowing depths was $0-30 \mathrm{~mm}$ with some species and cultivars emerging from greater depths than others. With some exceptions, larger seeds were generally able to germinate successfully from greater depths. It was reported that seeds of Brachiaria brizantha and Panicum maximum established better when covered by 20-50 mm. Generally, applying fertilizer nitrogen to seed crops has implications for yield component dynamics such as tiller increasing, number of fertile tillers, floret per spikelet, and seed per head and ultimately increases seed yield and quality. Amounts of nitrogen fertilizer required will depend on species, soil type and rainfall. More often, 100-250 kg of nitrogen per ha and crop and rate more than $300 \mathrm{~kg} \mathrm{~N} / \mathrm{ha}$ caused reduction in seed yield by severe plant lodging. For optimum time for nitrogen application, it can be recommended to growers to apply nitrogen in the period from vegetative to spikelet initiation.
\end{abstract}

(c) 2018 International Formulae Group. All rights reserved.

Keywords: Planting density, sowing, fertilization, seed yield, quality, tropical areas. 


\section{INTRODUCTION}

Seed production of forage species is a much earlier and less developed stage in the tropics and subtropics than in temperate regimes. Many of the current tropical forage cultivars were developed 50 years ago. Most of these grasses come from species new to agriculture. They have not undergone long period of domestication through hybridization and selection. Instead, they still retain many "wild characteristics" - attributes which aid their natural spread but pose difficulties for their commercial seed production. In many cases, detailed knowledge about their flowering habit and growth requirements is also lacking. All of this poses a challenge to seed producers who must decide where the various crops should be grown for seed, the best management strategy to apply in each case and when and how they should be harvested to maximize seed yield and quality.

Forage seed productions in tropical regions are characterized by variable production (Martiniello, 1999). Seed yield instability of the species may be a consequence of the contrasting environmental conditions that occur during the vegetative and reproductive growth of the crops (Clua and Gimenez, 2003). Seed yields of species, varieties or ecotypes that are widely used and well adapted to West Africa regions is not sufficient to meet the demand for seed suggested that studies on agronomic factors influencing the adaptability of species, varieties or ecotypes would be useful for determining agronomic techniques to increase seed production.

In short term, modifications of management practices is most likely to result in improved seed production (Adjolohoun 2008). Neglect of good cultural practices such as adequate site selection, seed bed preparation, correct seed rate, adequate sowing density and optimum level of fertiliser application can result in production of poor seed yield (Hopkinson et al., 1996). The effect of row spacing was variable on grasses seed production and there are a conflicting report in some cases depending on grass species, variety or ecotypes and environmental conditions. On the other hand, adequate levels of all nutrients are required for optimum crop development. In practice, however, the major factor limiting grass seed production is nitrogen (Brian, 2007). The present review describe practical processes involved for tropical seed production from site selection, land plowing, plant spacing, fertilizer management particularly nitrogen in tropical regions.

Research on fertilizer required by grass seed crops has tended to focus on rate and timing of application. Increasing nitrogen fertilizers is associated with an increase in seed yield until an optimum application is reached. Optimum rates vary widely in the literature, probably due to differences in soil nitrogen contribution, cropping history and type of grass. Furthermore, the range in maximum yields reported for some grasses suggests that in some reports, nitrogen was not the major limiting factor. Generalization about optimum fertilizer-nitrogen requirements should be therefore viewed with caution.

\section{SITE SELECTION}

The location of grass seed crops is a topic that can be approached from different point of views and different needs. At a broad policy level, the first decision to be made in relation to seed production is where best to grow the various species and cultivars required for forage use (Loch et al., 1999b). Firstly, the species or cultivars must be well adapted to the area for it to be able to produce a healthy, vigorous framework for a seed crop. Secondly, the environment at some point must be conducive to strong vigorous flowering by the plants. Thirdly, the flowering crop must be able to set and mature seed without significant impediments. Finally, conditions at crop maturity must be suitable for harvesting. Essentially, these requirements imply a sound knowledge of how the particular grass develops and any special requirements or restrictions it might have (Loch et al., 1999b). 
The full range of tropical and subtropical forage grasses is adapted across a wide diversity of environmental conditions so that no single area is ideal for producing seed of all species or cultivars. In practice, the determination of optimal production areas for each new grass is often a case of trial (Loch et al., 1999b). The main environmental factors that control flowering in tropical forage grasses are photoperiod (daylength) and temperature which interact with rainfall and humidity for determining the suitability of different localities for seed production (Hopkinson et al., 1996).

\section{LAND PREPARATION AND PLANT SOWING}

Most tropical grasses have small seeds compared with those of many arable crops (Buldgen et al. 2001). Because of this, a general recommendation is that these be sown no more than 10-30 mm deep. Essentially, the main is to cover the seed lightly or to firm it into the surface by rolling so that it can be covered lightly by soil washed into the various surface pockets and niches by rainfall. The effect of sowing depth was investigated in field experiments of many grasses. The conclusion was that optimum sowing depths was $0-30 \mathrm{~mm}$ with some species and cultivars emerging from greater depths than others. With some exceptions, larger seeds were generally able to germinate successfully from greater depths (Silue et al. 2017). It was reported that seeds of Brachiaria brizantha and Panicum maximum established better when covered by $20-40 \mathrm{~mm}$ and the smallerseed $P$. maximum at $20 \mathrm{~mm}$ (Adjolohoun 2008). By contract, A. gayanus did not need covering and established well from seed sown on the soil surface.

The planting of a pasture obviously necessities the supply of planting material which can be either vegetative plant parts or seed. A number of tropical grasses have, thus far, only been propagated from splits, stem cuttings, stolons or rhizomes. Of these grasses, Pennisetum purpureum, $P$. clandestinum, Digitaria decumbens and
Cynodon spp. are in widespread use throughout the tropical regions. Occasionally, certain grasses which could be grown from seed are propagated vegetatively if seed is scarce or considered expensive. That is the case of $P$. maximum, Andropogon gayanus and B. ruziziensis (Buldgen et al., 2001; Adjolohoun et al., 2013a; Adjolohoun et al., 2013b). Vegetative propagation is very labour-intensive and its success depends further on weather conditions after planting as dry spells kill vegetative material quicker than seed. In general, preference is attached to the use of seed when available.

\section{INFLUENCE OF ROW SPACING}

Whether the seed should be sown in rows or broadcast is a question often raised in relation to seed production. This also related to the overall issue of plant density and therefore seeding rate and seed placement. Optimum planting depends on its effect on seed yield and quality in many crops (Ogbonna et al., 2015; da Silva et al., 2016; Abu and Odo, 2017; Ngozi and Chidera 2017). Row planting has an advantage particularly with tussock grasses, such as Panicum, Andropogon, Pennisetum and Setaria species and seed production of Cenchrus spp. and B. ruziziensis are enhanced by row culture and proper nutrition (Adjolohoun et al., 2013b). Many studies have shown the advantage of row planting over broadcasting for grass seed production (Cook et al. 2005; Adjolohoun et al., 2013b; Olofintoye et al., 2015). Influence of row spacing can be studied through its effect on seed yield components, seed yield quantity or seed quality.

\section{Seed yield components}

The impact of plant density and row spacing on seed production can be seed most readily with short-lived perennial grasses such as Brachiaria deflexa or $B$. lata which were often treated as annual seed crops. The density of self-regenerating stands can also vary widely from year to year depending on the amount of readily germinable seed in the soil, 
weather conditions and management by the seed growers.

In some cases and in the longer term, spatial arrangements within a perennial stand cannot be as readily maintained or manipulated by the growers as in the first year or with annual crops. Over time, the individual plants increase in size. Initially, this way compensate for low density at planting but in some grasses (Paspalum notatum and $S$. sphacelata) it may result in a less productive stand that becomes sod-bound and moribund (Loch et al., 1999c). In such cases, it is important to start with a sufficiently open stand and to maintain this management.

The influence of row spacing on seed yield components had been variable. Various Cenchrus ciliaris seed yield attributes were affected significantly (both in the first and second year) by row spacing. In row spacing of 40, 60 and $75 \mathrm{~cm}$, plant height were 95, 119 and $124 \mathrm{~cm}$ respectively in the first experiment year and 105, 125 and $137 \mathrm{~cm}$ respectively in the second year (Kumar et al., 2005). Authors reported that the number of total and fertile tillers/tussock, spike length and number of spikelets/spike were significantly affected by row spacing $(75>60$ $>40 \mathrm{~cm}$ ). The superiority of the wider row spacing may be attributed to better transmission/distribution of light to the lower canopy, which resulted in greater tillering and inflorescence of these plants. A significant negative correlation was observed between row spacing and the number of days to $50 \%$ flowering (61, 59 and 61 days, respectively) and days to maturity (105, 109 and 112 days, respectively), suggesting that narrower row spacing hastened plant phonologies. Wider row spacing has also advantages as it enables farmers to undertake weed control during the early stages of establishment and to harvest seed as they can easily walk between the rows (Phaikaew et al., 2001a). In addition, those authors reported that larger inflorescences with wider row spacings make it easier to collect seed by covering inflorescences with nylon net bags. On the contrary, seeding rate showed no significant effect of tiller number in T. aestivum (Brian et al., 2007). For $P$. atratum, plant spacing did not have a significant effect on seed yield during 3-year experiment, but it significantly affected tiller and inflorescence densities, and size of inflorescence. Narrower plant spacing $(75 \mathrm{~cm}$ $\times 75 \mathrm{~cm}$ ) produced significantly more tillers and inflorescences $/ \mathrm{m}^{2}$ and smaller inflorescences (spikelet number/inflorescence) than the wider spacings. The wider plant spacings $(75 \mathrm{~cm} \times 100 \mathrm{~cm} ; 75 \mathrm{~cm} \times 125 \mathrm{~cm})$ produced larger inflorescences in compensation for fewer tillers and inflorescences $/ \mathrm{m}^{2}$ (Phaikaew et al., 2001a). $B$. humidicola was recommended to be sown at $100-200 \mathrm{~cm}$ row. Interaction between row spacing and soil fertility in particular nitrogen can make variable the influence of row spacing on seed components.

\section{Row spacing and seed yield}

Reports about the influence of row spacing on seed yield were not also consistent. Growing of pasture seed crops in rows, rather than in swards, is advocated for most species in the first cropping year, and for some species continuation in rows is recommended (Adjolohoun et al., 2013). Seed production is maximized at an optimum plant density or row spacing, with both very low and very high densities reducing seed yield in grasses (Kumar et al., 2005). Closer spacing did not favour seed production of $C$. ciliaris in experiment conducted by (Kumar et al., 2005). In fact, the highest seed yield (97 $\mathrm{kg} / \mathrm{ha}$ ) was recorded from the $75 \mathrm{~cm}$ row spacing. This was significantly higher than seed yields for $60 \mathrm{~cm}(83.7 \mathrm{~kg} / \mathrm{ha})$ and $40 \mathrm{~cm}$ $(75.9 \mathrm{~kg} / \mathrm{ha})$. Overall, seed at the widest spacing was $26 \%$ heavier than seed produced at the lowest spacing. Cook et al., (2005) had tested the influence of seeding rate on kikuyu grass $(P$. purpureum) seed production and found that with increasing seed rates from 5.6 to $89.6 \mathrm{~kg} / \mathrm{ha}(5.6,11.2,22.4,44.8$ and 89.6 $\mathrm{kg} / \mathrm{ha}$ ) seed yield increased in the first year and decreased in the second year. The low seed production in the second year is due to decumbent and procumbent culms which 
remained sparsely branched and did not produced seed.

The response to row spacings for seed production varies between species and even between cultivars for the same species as shown in Setaria sphacelata. Adjolohoun et al. (2008) recorded for S. sphacelata cv. Nandi II a lower yield of pure germinating seed from $90 \mathrm{~cm}$ rows than from 80 or $60 \mathrm{~cm}$ rows, although inflorescence densities at all three spacings were comparable. Not unexpectedly, Cook et al., (2005) found seed yield of $S$. sphacelata cv. Kazungula to be largely unaffected by row spacing (15-120 $\mathrm{cm})$ and density $\left(8-81\right.$ plants $\left.\mathrm{m}^{-2}\right)$. Cook et al., (2005) reported comparable seed yields from S. sphacelata CPI 32930 in $50 \mathrm{~cm}$ and $100 \mathrm{~cm}$ rows, but obtained higher yields at the narrower $50 \mathrm{~cm}$ spacing for $S$. sphacelata CPI 33452. Soil moisture conditions can also condition spacing row. For example, in drier areas, planting in wide rows improves the reliability of cropping because moisture and nutrients can be exploited throughout a greater soil area. In an experiment with Panicum coloratum, more seed was produced from 2.4 $\mathrm{m}$ rows than from equal numbers of plants in broadcast sward (Adjolohoun et al., 2008).

Interaction between row spacing and soil fertility in particular nitrogen can also make variable the influence of row spacing on seed yield. Adjolohoun et al. (2008) in his researches states that Setaria sphacelata with wider row spacing $(90 \mathrm{~cm})$ gave the highest seed yield at low soil nitrogen levels, but at higher levels of $\mathrm{N}$ fertilizer application, seed yield was the same over the range of 30-90 $\mathrm{cm}$ row spacing. Cook et al. (2005) also reported comparable seed yields at 50 and 100 $\mathrm{cm}$ row spacings with the same grass under higher $\mathrm{N}$ levels. Thus, he concluded that the wider row spacing can be recommended for seed production under limited soil $\mathrm{N}$ supply.

\section{Row spacing and seed quality}

Influence of row spacing on seed quality was also variable. Thousand-seed weight, seed germination, seed vigor index and seedling growth of buffel grass $C$. ciliaris increased with increasing row spacing (Kumar et al., 2005). The highest 100 -seed weight $(0.203 \mathrm{~g})$ of this grass recorded from a widely spaced crop $(75 \mathrm{~cm})$ was significantly higher than those recorded from $60 \mathrm{~cm}$ row spacing $(0.190 \mathrm{~g})$ and $40 \mathrm{~cm}$ row spacing $(0.175 \mathrm{~g})$. The main contributing factor to improve seedling vigor under the wider spacing was the higher 100-seed weight (bigger seeds) which resulted in higher germination and more vigor index. Contrary to the above results, Phaikaew et al. (2001a) noted variable conclusions for the influence of different plant spacings $(75 \mathrm{~cm} \times 75 \mathrm{~cm} ; 75 \mathrm{~cm} \times 100 \mathrm{~cm} ; 75$ $\mathrm{cm} \times 125 \mathrm{~cm}$ and $100 \mathrm{~cm} \times 100 \mathrm{~cm}$ ) on seed quality of Paspalum atratum during 3-year trial. In general, the narrower plant spacing produced heavier seed (100-seed weight) than the highest plant spacing. For seed germination, the second and third plant spacing produced more germinated seed than the two others. For seed purity, a significant interaction was recorded between plant spacing and year.

\section{INFLUENCE OF NITROGEN FERTILIZER}

The perfect soil for production of grass seed does not exist and all soils must be amended in some way to achieve optimum seed yield. Common amendments include soil nutrients such as nitrogen, phosphorus and potassium. Adequate levels of all nutrients are required for optimum crop development. In practice, however, the major factor limiting grass seed production is nitrogen (Loch et al., 1999a; Flávia et al., 2017; Raij, 2011). In most cropping soils plant-available nitrogen is present in insufficient quantities to allow plants to achieve maximum yields. This is not only because nitrogen is required in relatively large amount by plants (the dry matter of $A$. gayanus or $P$. maximum plants at young stage contains between $2-3 \%$ nitrogen) but also because nitrogen is highly mobile within the soil plant-atmosphere cycle. 


\section{$\mathbf{N}$ fertilizer and seed yield components}

Reports on the effect of nitrogen on seed production have been as conflicting as those on the effect of row spacing. In general, applying fertilizer nitrogen to seed crops has implications for yield component dynamics such as tiller increasing (Brian, 2007), number of fertile tillers ( $\mathrm{Li}$ and Zhao, 1993), tiller size, floret per tiller (Hare and Rolston, 1990) seed per head and ultimately increases seed yield and quality (Cook et al., 2005).

Application of different doses $(0,50$, $70,90,110,130$ and $150 \mathrm{~kg} / \mathrm{ha}$ ) of nitrogen had no significant effect on the number of panicle per tussock and heading date emergence of Oriza sativa (Jeon, 2012) but had significantly increased the number of panicle per $\mathrm{m}^{2}$. The positive response of tropical and subtropical grasses to nitrogen fertilizer resulted mainly from a combination of increased number of fertile tillers, greater spike length and more spikelets/spike (Loch et al., 1999a; Kumar et al., 2005). Influence of nitrogen fertilizer on seed yield components varies according to plant species and variety. Nitrogen fertilizer rates $(0,100$ and 400 $\mathrm{kg} / \mathrm{ha}$ ) for Paspalum plicatulum increased significantly tiller number and tiller fertility per surface unit but no significant difference was observed between 100 and $400 \mathrm{~kg}$ nitrogen per ha for those seed yield components (Cook et al. 2005).

In some cases, response of plant to nitrogen application can differ according to years depending to soil fertility. On fertile soil, Phaikaew et al., (2002) opined that $P$. atratum showed no significant difference in seed yield during first year trial after application of different $\mathrm{N}$ rates $(0,100,300$ and $400 \mathrm{~kg} / \mathrm{ha}$ ). However, in the second year, an application rate of $200 \mathrm{~kg} / \mathrm{ha} \mathrm{N}$ gave significantly higher seed yield than other $\mathrm{N}$ rates $(0,100,300$ and $400 \mathrm{~kg} / \mathrm{ha})$. Mean seed yields were higher in the first year than in the second year (1314 vs $704 \mathrm{~kg} / \mathrm{ha}$ ). The lower seed yields in the second year were principally due to lower inflorescence numbers caused by a decrease in the percentage of effective tillers, and reduced raceme numbers/inflorescence, giving fewer seed numbers $/ \mathrm{m}^{2}$. These components were not affected by $\mathrm{N}$ rates in the first year, but differed among nitrogen rates in the second year. The highest seed yield at nitrogen rate of $200 \mathrm{~kg} / \mathrm{ha}$ (due to highest seed number $/ \mathrm{m}^{2}$ ) was a function of the combination of higher inflorescence number with higher seed number/inflorescence than at other rates. Inflorescence density, that is, the number of effective tillers per unit area, decreased above rate of $200 \mathrm{~kg} / \mathrm{ha}$. The only significant variations among treatments occurred in the second year and were in seed yield, inflorescence number, racemes/inflorescence, spikelet numbers/raceme, seed numbers $/ \mathrm{m}^{2}$ and seed numbers/inflorescence. Parihar et al. (1998) also showed that different rates of nitrogen fertiliser varying between 0 and 400 $\mathrm{kg} / \mathrm{ha}$ have no effect on vetiver grass (Vetiveria zizanioides), tiller density and fertility either on fertile and unfertile soil in the first year establishment but affected those parameters in a subsequent years.

\section{$\mathbf{N}$ fertilizer and seed yield}

Reports about the influence of nitrogen fertilizer on seed production were also variable. Nitrogen increased generally seed yield for tropical and subtropical crops (Adjolohoun et al., 2013; Paulo, 2014). For $C$. ciliaris, rates of 20,40 and $60 \mathrm{~kg} / \mathrm{ha}$ produced $54.6,57.6$ and $61.7 \mathrm{~kg} / \mathrm{ha}$, respectively in year 1 and $80.1,86.3$ and $90.1 \mathrm{~kg} / \mathrm{ha}$, respectively in year 2). A significant difference was noted between seed yield recorded for both two years. In Thailand, Gobius et al. (2001) recorded a significant increase in seed yield with the intermediate (40 kg N/ha) and high $\mathrm{N}$ (60 kg N/ha) levels over the low level of $\mathrm{N}$ (20 kg N/ha) in B. decumbens, Digitaria milanjiana and A. gayanus. These results suggested that seed yields may, in some circumstances, be higher in the first year than in subsequent years (Hacker, 1994; Phaikaew et al., 2001a, 2001b). Requirements for applied $\mathrm{N}$ tend to be the lowest in the establishment year presumably due to availability of previous soil nutrients 
particularly to the mineralization of nitrogen in the soil that follows cultivation.

Although nitrogen fertilizer generally increases seed yield, it can produce no significant effect in some cases as for Triticum aestivum (Brian et al., 2007) or even depletion effect by reduction seed yield with increasing nitrogen fertilizer rates (Cookson et al., 2000; Phaikaew et al., 2002).

\section{$\mathbf{N}$ fertilizer and seed quality}

Reports on effect of nitrogen on seed quality were variable according to species and environments. Different rates of $\mathrm{N}$ fertiliser $(50,100$ and $200 \mathrm{~kg} / \mathrm{ha})$ had no significant effect on seed weight, seed purity, seed germination and seed viability of $B$. decumbens, D. milanjiana, A. gayanus and $C$. sphalcelata (Gobius et al., 2001; Dwivedi et al., 1999). Similarly, different doses of nitrogen fertilizer (20, 40 and $60 \mathrm{~kg} \mathrm{~N} / \mathrm{ha}$ ) had also produced no significant effect on $C$. ciliaris seed weight, seed germination, seedling length and seed vigour index (Kumar et al., 2005). For Phaikaew et al. (2002), seed weight, seed purity and seed germination of $P$. atratum were not affected by nitrogen application $(0,100,200,300$ and $400 \mathrm{~kg}$ $\mathrm{N} / \mathrm{ha}$ ) in the first year trial but seed weight and seed germination were significantly affected in second year. Conversely, thousand kernel weight of $T$. aestivum decreased with increasing nitrogen level (Brian et al., 2007) and nitrogen application decreased seed weight, seed purity and seed germination of $P$. plicatulum (Cook et al., 2005).

\section{OPTIMUM NITROGEN APPLICATION RATE}

There have also been a number of experiments to determine optimum rates for various species or cultivars. As a general guide, rates near the optimum lead to minimal lodging in most grasses and the growing crop should retain darker green leaves until about inflorescence emerge, after which it lightens in colour as it matures. At above optimal levels, the degree of lodging will increase dramatically; the crop should retain a darker colour through the maturity; and aerial tillering leading to late inflorescence emergence is triggered by moisture. At suboptimal levels, the crop will begin to lighten in colour during the vegetative phase as $\mathrm{N}$ becomes depleted, so it produces fewer inflorescences. The determination of plant nitrogen requirement for seed production allows seed growers to avoid over-or underapplication and leads to high nitrogen-use efficiency (Adjolohoun et al., 2008; Somba et al., 2017; Bilong et al., 2017; Laibi et al., 2017).

Lower rates of $\mathrm{N}$ are required in the establishment year than for subsequent years. In sub-humid environments, experiments on established crops of $C$. gayana, Eragrostis curvula, P. plicatulum and Setaria sphalcelata have recorded maximum seed yields at about $100 \mathrm{~kg} \mathrm{~N} / \mathrm{ha}$ per crop, but the $\mathrm{N}$ requirements of others grasses can vary considerably. Lower optima have been reported for Brachiaria mutica and Pennisetum clandestinum. At the other extreme, seed yield has continued to increase in some experiments up to $150-200 \mathrm{~N} / \mathrm{ha} / \mathrm{crop}$, sometimes without reaching a turning point. The need for fertilizer nitrogen is lower on more fertile soils and may be reduced by residual $\mathrm{N}$ from the previous crop. Generally rate more than 200-300 kg N/ha had caused reduction in seed yield by severe plant lodging (Phaikaew et al., 2002; Gobius et al., 2001) or toxicity effect of ammonium nitrate or sulfate in some cases (Paulo et al., 2014).

\section{OPTIMUM TIME OF APPLICATION}

Because Nitrogen plays such a central role in determining grass seed yield, one of the key decisions is when this should be done. Using P. plicatulum, Cook et al. (2005) showed the importance for the developing crop in maintaining adequate nitrogen up until the stage of inflorescence emergence but fund that differences in nitrogen supply had little or no effect during the final phases of flowering and seed maturation. Optimum response of nitrogen application is thought to be achieved 
by applying nitrogen fertilizer between spikelet initiation and stem elongation. It has been shown for plant the requirement for fertilizer and the timing of its application in relation to the developmental stages of the crops are important. To maximize inflorescence number, fertilizer $\mathrm{N}$ should therefore be applied when grazing or defoliation ceases and the seed crop is allowed to develop (Cook et al., 2005). The early application of $\mathrm{N}$ stimulates and synchronizes tiller development and promotes early closure of the crop canopy leading to the virtual cessation of further tillering until the reproductive phase (Loch and Ferguson, 1999). However, recent studies indicate that nitrogen deficiency in the period from vegetative to spikelet initiation also restrict seed yield. Delaying application of nitrogen tends to reduce number of fertile tillers which is often related to a decrease in seed yield. The balance between early or late application has also received attention, and, again, recommendations vary. In general, seed yield in tropical region have been shown to respond to fertilizer-nitrogen applied one third in at sowing and two thirds at the beginning of elongation time (Buldgen and Dieng, 1997). Nitrogen applications during the vegetative and initiation floral stages were most efficient for seed production. For other grasses, researches must be led (using for example $\mathrm{N}^{15}$ ) to establish for each species or variety the contribution of different timing of nitrogen application to final seed yield.

\section{Conclusion}

It is essential to establish plant at optimum row spacing for ensuring an adequate population of plants for seed production. Researches on the effects of the rate and method of fertiliser application or row spacing on African forage seed production are either scarce or have produced contradictory results due to the specific characteristics (still wild nature plant). For any grass species or variety, recommendation for planting density or nitrogen fertilizer must be specific, since differences in soil fertility, climatic conditions, water availability, cropping management and the age of the crop, must be taken into account. Where grass is sown for seed production under good fertility conditions, it is probable that nitrogen need not be applied at sowing time. At lower levels of fertility a nitrogen fertilizer may be advisable, even at sowing time. In subsequent years, increasing nitrogen fertilizer levels would be necessary. The question of dividing the application cannot be decided for all species or varieties but there are indications that this may be desirable to split according to soil characteristics and rainfall conditions. Environment appears to be important in such seed production and quality and therefore, there is a need of case-by-case study for each species/cultivar and environment because conflicting reports don't allow their extending to other environments.

\section{COMPETING INTERESTS}

Authors have declared that no competing interests exist.

\section{AUTHORS' CONTRIBUTIONS}

This work was carried out in collaboration between all authors. BG designed the study, performed documentation research, was involved in data collection, and wrote the first draft of the manuscript. SA and others managed on data collection, evaluation and interpretations. All authors read and approved the final manuscript.

\section{ACKNOWLEDGEMENTS}

We humbly appreciate the breathtaking effort of all that contributed immensely to the successful completion of this work. 


\section{REFERENCES}

Adjolohoun S. 2008. Yield, nutritive value and effects on soil fertility of forage grasses and legumes cultivated as ley pastures in the Borgou region of Benin. $\mathrm{PhD}$ thesis, Faculty of Agronomy Science of Gembloux, Belgique, p. 101.

Adjolohoun S, Bindelle J, Adandedjan C, Toléba SS, Houinato M, Kindomihou V, Nonfon WRV, Sinsin B. 2013. Influence de l'écartement et de la fertilisation azotée sur le rendement et la qualité des semences de Brachiaria ruziziensis en climat tropical sub-humide, Fourrages, 216: 339-345.

Adjolohoun S, Dahouda M, Adandedjan C, Toleba SS, Houinato M, Nonfon R, Sinsin AB. 2013a. Diversité et caractérisation morphologique des écotypes de l'espèce fourragère Panicum maximum au Bénin. Int. J. Biol. Chem. Sci., 6(5): 2043-2054. DOI: http://dx.doi.org/10.4314/ijbcs.v6i5.14

Adjolohoun S, Bindelle J, Adandedjan C, Toleba SS, Houinato M, kindomihou V, Nonfon WRV, Sinsin B. 2013 b. Influence de l'écartement et de la fertilisation azotée sur le rendement et la qualité des semences de Brachiaria ruziziensis en climat tropical subhumide. Fourrages, 216: 339-345.

Bilong EG, Ajebesone FN, Abossolo-Angue M, Madong BA, Bonguen SMN, Bilong P. 2017. Effets des biomasses vertes de Tithonia diversifolia et des engrais minéraux sur la croissance, le développement et le rendement du manioc (Manihot esculenta Crantz) en zones forestières du Cameroun. Int. J. Biol. Chem. Sci., 11(4): 1716-1726. DOI: http://dx.doi.org/10.4314/ijbcs.v11i4.24

Brian NO, Mohamed M, Joel KR. 2007. Seeding Rate and Nitrogen Management Effects on Spring Wheat Yield and Yield
Components. Agronomy J., 99: 16151621.

Buldgen A, Dieng A. 1997. Andropogon gayanus var. bisquamulatus. Une Culture Fourragère pour les Regions Tropicales. Les presses Agronomiques de Gembloux: Gembloux, Belgique; 171.

Buldgen A, Michiels B, Adjolohoun S, Babatoundé S, Adandédjan C. 2001. Production and nutritive value of grasses cultivated in the coastal area of Benin. Trop. Grassl., 35: 43-47.

Clua AA, Gimenez DO. 2003. Environmental factors during seed development of narrow-leaved bird's-foot-trefoil (Lotus tenuis) influences subsequent dormancy and germination. Grass and Forage Science, 58: 333-338.

Cookson WR, Rowarth JS, Cameron KC. 2000. The response of a perennial ryegrass (Lolium perenne L.) seed crop to nitrogen fertilizer application in the absence of moisture stress. Grass and Forage Science, 55: 314-325.

Cook BG, Pengelly BC, Brown SD, Donnelly JL, Eagles DA, Franco MA, Hanson J, Mullen BF, Partridge IJ, Peters M, Schultze-Kraft R. 2005. The Production of Tropical Forages: An Alternative Selection tool. Available at <http://www.tropicalforages.info>; accessed on [15/12/2017]

da Silva TJA, Duarte TF, Sousa JVR, BonfimSilva EMB, Pacheco AB, de Sousa HHF. 2016. Soil moisture and water use efficiency in cotton plants grown in different spacings in the Brazilian Cerrado Region. Afric. J. Agric. Res., 11(8): 701-708.

Dwivedi GK, Kumar D, Tomer PS. 1999. Effect of cutting management and nitrogen levels on growth, seed yield attributes and seed production of Setaria 
sphacelata cv. Nandi. Trop. Grassl., 33: 146-149.

Flávia MAG, Henrique ZB, Luciana G, Alessandra AG, Karina B, Waldssimiler TM, Linda MP, Alberto Nagib VM. 2017. The utilization of tropical legumes to provide nitrogen to pastures: A review. Afri. J. Agric. Res., 12(2): 85-92.

Gobius NR, Phaikaew C, Pholsen P, Rodchompoo O, Susena W. 2001. Seed yield and its components of Brachiaria decumbens cv. Basilisk, Digitaria milanjiana cv. Jarra and Andropogon gayanus cv. Kent in north-east. Trop. Grassl., 35: 26-33.

Hacker JB. 1994. Seed production and its components in bred populations and cultivars of winter-green Setaria sphacelata at two levels of applied nitrogen fertilizer. Austr. J. Exp. Agric., 34: 153-160.

Hare MD, Rolston MP. 1990. Nitrogen effects on tall fescue seed production. Journal of Applied Seed Production, 8: 28-32.

Hebblethwaite PD, Ivins JD. 1977. Nitrogen studies in Lolium perenne grown for seed II. Journal of British Grasslands Society, 32: 195-204.

Hopkinson JM, Souza FHD, De Diulgheroff S, Ortiz A, Sánchez M. 1996. Reproductive physiology, seed production and seed quality of Brachiaria. In Brachiaria: Biology, Agronomy and Improvement, Milles JW, Maass BL, Valle CB, Kumble V (eds). CIAT Publication: Cali, Colombia; 124140.

Jeon WT. 2012. Effects of nitrogen levels on growth, yield and nitrogen uptake of fiber-rich cultivar, Goami 2. Afric. J. Biotech., 11(1): 131-137.

Kumar D, Dwivedi GK, Singh SN. 2005. Seed yield and quality of buffel grass (Cenchrus ciliaris) as influenced by row spacing and fertilizer level. Trop. Grassl., 39: 107-111.

Laibi AB, Gomina M, Sorgho B, Sagbo E, Blanchart P, Boutouil M, Sohounhloule DKC. 2017. Caractérisation physicochimique et géotechnique de deux sites argileux du Bénin en vue de leur valorisation dans l'éco-construction. Int. J. Biol. Chem. Sci., 11(1): 499-514. DOI: http://dx.doi.org/10.4314/ijbcs.v11i1.40

Li S, Zhao JQ. 1993. Effect of levels of nitrogen fertilizer on the yield of clean seed and dry matter of Setaria sphalcelata cv. Narok in South-West China. Proceedings of the XVII. International Grasslands Congress, 264266.

Loch DS, Ramírez Avilés L, Larvey GL. 1999a. Crop management: Grasses. In Forage Seed Production (vol 2): Tropical and Subtropical Species, Loch DS, Ferguson JE (eds). CAB Int; 141155.

Loch DS, Cook BJ, Harvey GL. 1999 b. Location of seed crops: Grasses. In Forage Seed Production (vol 2): Tropical and Subtropical Species, Loch DS, Ferguson JE (eds). CAB Int; 113128.

Loch DS, Cook BJ, Harvey GL. 1999c. Crops establishment: In Forage Seed Production (vol 2): Tropical and Subtropical Species, Loch DS, Ferguson JE (eds). CAB Int; 141-157.

Martiniello P. 1999. Effect of irrigation and harvest management on dry matter yield and seed yield of annual clovers grown in pure stand and in mixtures with graminaceous species in a Mediterranean environment. Grass and Forage Science, 54: 52-61.

Ngozi EA, Chidera VO. 2017. The effect of plant density on growth and yield of 'NsukkaYellow' aromatic pepper 
(Capsicum anпиит L.). Afric. J. Agric. Res., 12(15): 1269-1272.

Ogbonna PE, Orji KO, Nweze NJ, Opata PI. 2015. Effect of planting space on plant population at harvest and tuber yield in taro (Colocasia esculenta L.). Afric. J. Agric. Res., 10(5): 308-316.

Olofintoye JAT, Abayomi YA, Olugbemi O. 2015. Yield responses of grain amaranth (Amaranthus cruentus L.) varieties to varying planting density and soil amendment. Afric. J. Agric. Res., 10(21): 2118-2225.

Parihar SS, Mal B, Shankar V, Kak A. 1998. Seed production and germination in vetiver grass (Vetiveria zizanioides). Trop Grassl., 32: 173-177.

Paulo RL, Ricardo EC, Augustinho B, Ecco M, Martios E, Fernando VF, Eder JM, Léandro R, Jean SR, André GB, Ubirajara CM, Paulo RB. 2014. Effects of different rates of nitrogen $(\mathrm{N})$ and phosphorus pentoxide $\left(\mathrm{P}_{2} \mathrm{O}_{5}\right)$ on eggplant yield. Afric. J. Agric. Res., 9(19): 1435-1441.

Phaikaew C, Pholsen P, Tudsri S, Tsuzuki E, Numaguchi H, Ishii Y. 2001a. Maximising seed yield and seed quality of Paspalum atratum through choice of harvest method. Trop. Grassl., 35: 1118.
Phaikaew C, Khemsawat C, Tudsri S, Ishii Y, Numaguchi H, Tsuzuki E. 2001b. Effects of plant spacing and sowing time on seed yield and seed quality of Paspalum atratum in Thailand. Trop. Grassl., 35: 129-138.

Phaikaew C, Nakamanee G, Intarit S, Tudsri S, Ishii Y, Numaguchi H, Tsuzuki E. 2002. Effects of soil fertility and fertiliser nitrogen rate on seed yield and seed quality of Paspalum atratum in Thailand. Trop. Grassl., 36: 138-149.

Raij BV 2011. Fertilidade do solo e manejo de nutrientes. Piracicaba: International Plant Nutrition Institute, p. 420.

Silue PA, Kouassi KE, Koffi KAD, Soro D. 2017. Qualités germinatives des graines et croissance des plantules de Isoberlinia $s p p$ en milieu contrôlé (pépinière). Int. J. Biol. Chem. Sci., 11(1): 93-106, DOI : http://dx.doi.org/10.4314ijbcs.v11i1.8

Somba BB, Ouattara B, Serme I, Mathias B, Pouya MB, Lompo F, Taonda SJB, Sedogo PM. 2017. Détermination des doses optimales de fumures organominérales en microdose dans la zone soudano-sahélienne du Burkina Faso. Int. J. Biol. Chem. Sci., 11(2): 670-683. DOI:http://dx.doi.org/10.4314/ijbcs.v11i 2.11 . 